\title{
A review of green- and blue-water resources and their trade-offs for future agricultural production in the Amazon Basin: what could irrigated agriculture mean for Amazonia?
}

\author{
Michael J. Lathuillière ${ }^{1}$, Michael T. Coe ${ }^{2}$, and Mark S. Johnson ${ }^{1,3}$ \\ ${ }^{1}$ Institute for Resources, Environment and Sustainability, University of British Columbia, 2202, Main Mall, Vancouver, B.C., \\ V6T 1Z4, Canada \\ ${ }^{2}$ Woods Hole Research Center, 149 Woods Hole Road, Falmouth, MA 02540-1644, USA \\ ${ }^{3}$ Department of Earth, Ocean and Atmospheric Sciences, University of British Columbia, 2207, Main Mall, Vancouver, B.C., \\ V6T 1Z4, Canada
}

Correspondence to: Michael J. Lathuillière (mlathuilliere@ alumni.ubc.ca)

Received: 12 February 2016 - Published in Hydrol. Earth Syst. Sci. Discuss.: 19 February 2016

Revised: 6 May 2016 - Accepted: 19 May 2016 - Published: 7 June 2016

\begin{abstract}
The Amazon Basin is a region of global importance for the carbon and hydrological cycles, a biodiversity hotspot, and a potential centre for future economic development. The region is also a major source of water vapour recycled into continental precipitation through evapotranspiration processes. This review applies an ecohydrological approach to Amazonia's water cycle by looking at contributions of water resources in the context of future agricultural production. At present, agriculture in the region is primarily rain-fed and relies almost exclusively on green-water resources (soil moisture regenerated by precipitation). Future agricultural development, however, will likely follow pathways that include irrigation from blue-water sources (surface water and groundwater) as insurance from variability in precipitation. In this review, we first provide an updated summary of the green-blue ecohydrological framework before describing past trends in Amazonia's water resources within the context of land use and land cover change. We then describe green- and blue-water trade-offs in light of future agricultural production and potential irrigation to assess costs and benefits to terrestrial ecosystems, particularly land and biodiversity protection, and regional precipitation recycling. Management of green water is needed, particularly at the agricultural frontier located in the headwaters of major tributaries to the Amazon River, and home to key downstream blue-water users and ecosystem services, including domestic and industrial users, as well as aquatic ecosystems.
\end{abstract}

\section{Introduction}

The role of ecosystems in the global hydrological cycle has been the foundation of global ecohydrology over the past 50 years (Dolman et al., 2014). Advances in the areas of remote sensing and land-atmosphere modelling have widened our understanding of ecosystems in the global carbon and hydrological cycles, and identified important global trends in evapotranspiration (ET). These trends include an apparent slowdown in global ET in recent decades and possible increase in continental ET in South America (see Supplement). The global ET decline has been attributed not only to increased atmospheric $\mathrm{CO}_{2}$ concentrations and nitrogen deposition but also to changes in land use and soil moisture stocks (Jung et al., 2009; Mao et al., 2015).

Soil moisture plays an important ecohydrological role. To highlight its importance, Falkenmark and Rockström (2004) proposed to shift the traditional notion of the freshwater source from surface water or groundwater resources to precipitation. As precipitation reaches the soil surface, it is partitioned into two distinct resources: "blue" water represents runoff, rivers, reservoirs, wetlands, and aquifers (liquid stocks); "green" water is the soil moisture found in the soil's unsaturated zone, either reclaimed by the atmosphere through soil evaporation or consumed by the vegetation via root uptake and lost through transpiration during photosynthesis (Falkenmark and Rockström, 2004). Precipitation over land is recycled exclusively through ET processes, of which 
about two-thirds are supplied by plant transpiration (Gerten et al., 2005; Rost et al., 2008), thus making green water an essential ecohydrological resource that merits scientific investigation.

We propose to apply this framework to water resources in the Amazon region within the context of food production and security, freshwater availability, and global climate change. In recent decades, the region has experienced significant deforestation for agricultural expansion of soybean, maize, and pasture (Fearnside, 2005; Barona et al., 2010; Macedo et al, 2012; Nepstad et al., 2014), while exhibiting the effects of apparent changes in climate from El Niño events, two historical droughts in 2005 and 2010 (Davidson et al., 2012), and possible land-use-driven atmospheric feedbacks affecting precipitation (Spracklen et al., 2012; Bagley et al., 2014; Spracklen and Garcia-Carrera, 2015). South-eastern Amazonia, in particular, is sensitive to future anthropogenic and climate changes (Coe et al., 2013). Its location in the headwaters of major tributaries of the Amazon River and a key node in the global food system also make it an important geographical player in land and water management.

Southern Amazonia is a regional hotspot for potential trade-offs in green- and blue-water resources between upstream and downstream users. Agricultural expansion and especially the use of irrigation remain important options for consideration this century as these trade-offs are intrinsically linked to land management decisions. South-eastern Amazonia currently has high crop yields, comparable to those in the United States, of about $3 \mathrm{tha}^{-1}$ for soybean and 5-6 tha ${ }^{-1}$ for maize (IBGE, 2015). Therefore, production can increase only marginally through improvements in rain-fed practices. Deforestation and agricultural expansion in Amazonia have been thoroughly examined using land use change trajectories and including the potential effects of atmospheric $\mathrm{CO}_{2}$ concentration on future agricultural yields and river discharge (e.g. Coe et al., 2009, 2011; Oliveira et al., 2013; Pokhrel et al., 2014), but these studies have not examined possible expansion of the use of irrigation in agriculture and the impacts that this freshwater consumption could have on groundwater resources, river discharge, and climate.

First, we provide a brief description of green- and bluewater resources (Sect. 2) as a way to frame Amazonia's land and water management in the context of agricultural production (Sect. 3). Following additional discussion on greenand blue-water trade-offs with land use change in Amazonia (Sect. 3), we discuss possible regional changes to the water cycle and atmospheric water balance as a result of conversion of natural ecosystems and pasture to agricultural production, with a specific focus on the adoption of widespread irrigation as a feasible scenario (Sect. 4).

\section{Green and blue water as a foundation for ecohydrology}

\subsection{Defining an ecohydrological paradigm for water resources}

Falkenmark and Rockström (2004) initiated a paradigm shift in water resource management by proposing to change the traditional notion of the freshwater source from rivers, reservoirs, and aquifers to precipitation. In their description of water resources, precipitation is partitioned at the soil surface into blue water (as surface or groundwater) and green water (as soil moisture regenerated by precipitation), typically absent in water management considerations (Falkenmark and Rockström, 2004, 2006). Traditional blue-water management considers ET as a flow of water lost to the atmosphere (Oki and Kanae, 2006), while green-water resource management calls for a focus on vapour supply to the atmosphere for precipitation recycling (Falkenmark and Rockström, 2004, 2006; Ellison et al., 2012). On the land, such vapour supply is represented by green water consumed mainly by ET but also by some unconsumed water that is returned to the atmosphere through evaporation from soil moisture, snow, or ice sublimation, and evaporation of water intercepted by human made or natural landscapes.

Blue and green water are distinguished by their physical state as well as the processes, frequency, and factors of influence that govern their consumptive uses (Table 1). Consumptive uses are different from water withdrawals in that withdrawals can be returned to the blue water cycle, whereas consumptive uses cannot (Rockström et al., 2010). Bluewater consumptive uses include some fraction of drinking water, evaporative losses through cropland irrigation or hydropower, and incorporation of water into products. Greenwater consumptive uses exclusively occur through ET with a distinction between productive and unproductive vapour flows characterized respectively by transpiration and direct evaporation of soil moisture (Falkenmark and Rockström, 2006).

Aquatic ecosystems rely exclusively on blue water and may require inflows of surface water or groundwater to ensure proper function (e.g. wetlands, fisheries). Blue water is shared between humans and ecosystems such that a consumption activity will require blue-water trade-offs between users. Green-water resources are exclusively consumed through ET processes and, as such, are consumed only once by terrestrial ecosystems, in the case of productive green-water consumption, before returning to the atmosphere (Rockström and Gordon, 2001). Evaporation of soil moisture or water intercepted by canopies also regenerates precipitation unproductively, meaning the process does not support any additional human or ecosystem activity, although the latent heat uptake from evaporation can be important to regional water balances (Biggs et al., 2008). Water vapour flows resulting from blue-water consumption (Karlberg et al., 
Table 1. Representation of water resource terminology in the green- and blue- water ecohydrological approach (Falkenmark and Rockström, 2004, 2006).

\begin{tabular}{llll}
\hline Water & Stock & Flow & Consumptive pathway \\
\hline Precipitation & Atmosphere & Liquid, solid & Source \\
\hline Blue & $\begin{array}{l}\text { Runoff, rivers, reservoirs, } \\
\text { wetlands, lakes, snowpack, } \\
\text { aquifers }\end{array}$ & Liquid & $\begin{array}{l}\text { Household or industrial uses, } \\
\text { drinking water, product } \\
\text { integration }\end{array}$ \\
\hline Blue & Surface water or groundwater & Vapour & $\begin{array}{l}\text { Evapotranspiration from } \\
\text { irrigation }\end{array}$ \\
\hline $\begin{array}{l}\text { Green, } \\
\text { productive } \\
\text { green }\end{array}$ & Soil moisture & Vapour & Plant transpiration \\
\hline $\begin{array}{l}\text { Green, } \\
\text { unproductive } \\
\text { green }\end{array}$ & $\begin{array}{l}\text { Soil moisture, intercepted } \\
\text { rainfall }\end{array}$ & Vapour & $\begin{array}{l}\text { Evaporation (soil, surface, } \\
\text { snow) }\end{array}$ \\
\hline
\end{tabular}

2009) illustrate the special case of ET from irrigation, a bluewater resource.

The above representation of the water source as precipitation and its partitioning into blue- and green-water resources brings new considerations to water resource management: the importance of vapour flows and precipitation recycling, as well as potential blue- and green-water trade-offs with land management discussed below.

\subsection{Precipitation recycling and green- and blue-water trade-offs}

By emphasizing the importance of green-water resources, Falkenmark and Rockström (2004) highlighted the need to regenerate rainfall through ET to ensure a continuation in the supply of precipitation, the water source in the above paradigm. Precipitation recycling occurs at different scales when considering local (e.g. same watershed), regional, or continental effects since regional terrestrial recycling is generally larger than local recycling (40 and $13 \%$ respectively; Ellison et al., 2012) and increases as a function of area (van der Ent et al., 2010). It is estimated that about $65 \%$ of global terrestrial precipitation is sourced from terrestrial water vapour flows to the atmosphere (Karlberg et al., 2009) (Table S1 in the Supplement), with the remaining 35\% sourced by evaporation from oceans and other water surfaces (liquid, ice, and snow) (Oki and Kanae, 2006). Green-water resources therefore recharge "atmospheric watersheds" or "precipitationsheds" which connect soil moisture evapotranspired from one source region to a sink region, further downwind (Keys et al., 2012). As ET is typically water-limited in arid, semi-arid, and highly seasonal environments, these regions are particularly reliant on green-water resources to regenerate precipitation (Falkenmark and Rockström, 2004, 2006; Rockström et al., 2010).
Key terrestrial ecosystem services are maintained through the consumption of green-water resources, including agroecosystems, with vapour flows ensuring $90 \%$ of global human needs (Rockström and Gordon, 2001). Global terrestrial ecosystems were estimated to supply 42900 $45646 \mathrm{~km}^{3} \mathrm{yr}^{-1}$ of water vapour through transpiration, while $14682-15478 \mathrm{~km}^{3} \mathrm{yr}^{-1}$ of water vapour is estimated to be supplied by rain-fed agroecosystems (cropland and pasture) (Gerten et al., 2005; Rost et al., 2008).

Since green- and blue-water resources emerge through the partitioning of precipitation at the soil interface, there are green- and blue-water trade-offs with every land use decision (Karlberg et al., 2009). Several models have attempted to provide annual average ET estimates for major biomes of the world (Table S3), which highlight partitioning of precipitation and potential trade-offs based on vegetation and climate. These trade-offs depend on the ecohydrological relationship between the vegetation and the water cycle, which can be explained through environmental and physiological controls on ET. Environmental controls are illustrated by the relationship linking energy, climate, vegetation, and land use. In 299 basins, Zeng et al. (2012) found strong correlations between ET and mean annual temperature $(R=0.68)$, annual precipitation $(R=0.87)$, and NDVI $(R=0.70)$. Analysis of 21 tropical eddy covariance sites showed a strong correlation of latent heat flux with net radiation $\left(R^{2}=0.72\right)$ but weak correlations with vapour pressure deficit $\left(R^{2}=0.14\right)$ and NDVI $\left(R^{2}=0.09\right)$ (Fisher et al., 2009). These relationships show the dependence of ET on green-water supply and environmental demand (sensu Christoffersen et al., 2014).

Changing the landscape can affect both environmental and physiological controls on ET with consequences on greenand blue-water trade-offs. There being shallower root systems of crops or pasture compared to woodlands or tropical forest is one important morphological condition that ex- 
plains differences in precipitation partitioning (Table S3) in addition to the amount of water supplied by precipitation or access to deep groundwater (blue water) reserves (Matyas and Sun, 2014). Declines in ET from the landscape due to changes in climate or land use can lead to an increase in blue water downstream due to runoff (Karlberg et al., 2009) and consequently a reduction in moisture recycling to regenerate precipitation locally (Savenije, 1995, 1996). However, the scale of these processes is an important consideration since reduced precipitation recycling at regional scales can also decrease blue water by lowering rainfall inputs into rivers (Ellison et al., 2012).

Research linking global agricultural practices to changes in vapour flows has emphasized the importance of deforestation and irrigation expansion in some regions with expected consequences on precipitationsheds (Keys et al., 2012). Deforestation was estimated to have reduced transpiration by over $100 \mathrm{~mm} \mathrm{yr}^{-1}$ in regions of intensive land use and land cover change, with a $7.4 \%$ decrease in transpiration simulated globally for the 1961-1990 period (Gerten et al., 2005). Another study concludes that agricultural expansion through deforestation led to a global water vapour loss of $3000 \mathrm{~km}^{3} \mathrm{yr}^{-1}$, while irrigation expansion has increased flows by $2600 \mathrm{~km}^{3} \mathrm{yr}^{-1}$, suggesting only a small net loss due to land use and cover change (Gordon et al., 2005). In parallel, Gerten et al. (2005) also predict a $2.2 \%$ increase in runoff, while Rost et al. (2008) estimate a $5 \%$ increase in river discharge accompanying a $2.8 \%$ decrease in ET from land use change and a $1.9 \%$ increase in ET from irrigation. Such trade-offs would tip the balance toward greater bluewater yields. However, the question of scale needs to be addressed as precipitation recycling might counteract this effect and so, just like global changes in ET, global changes in runoff might not represent regional effects. Reductions in ET can lessen precipitation hundreds or thousands of kilometres away, thus also impacting river discharge (Coe et al., 2009, 2011; Ellison et al., 2012; Spracklen et al., 2012; Stickler et al., 2013; Spracklen and Garcia-Carrera, 2015).

\subsection{The role of green water in agriculture}

As the largest consumer of water resources, agriculture has been the focal point of early research on green and blue water. An additional 1700 and $1550 \mathrm{~km}^{3} \mathrm{yr}^{-1}$ of water consumptive use is expected for increases in food production and carbon sequestration projected for 2050 respectively, compared to the current total blue-water consumptive use of $2600 \mathrm{~km}^{3} \mathrm{yr}^{-1}$ (Rockström et al., 2014). This combined $5800 \mathrm{~km}^{3} \mathrm{yr}^{-1}$ approaches the upper limit of the estimated planetary boundary of $4000-6000 \mathrm{~km}^{3} \mathrm{yr}^{-1}$ (Rockström et al., 2014); given that blue-water resources are already stressed in many regions of the world, there seems to be limited opportunity to feed the world solely through irrigation expansion.
Green-water consumption in rain-fed agriculture represents about $75 \%$ of total cropland consumptive use (green and blue water), which is $4-5$ times greater than bluewater consumptive use in irrigation according to seven global models (Hoff et al., 2010). Estimates of global cropland ET were predicted to be between 3272 and $7200 \mathrm{~km}^{3} \mathrm{yr}^{-1}$ based on models considered, while pasture ET exceeds $4000 \mathrm{~km}^{3} \mathrm{yr}^{-1}$. Rain-fed agriculture is often key to securing the livelihoods of those living in poverty, especially in drylands or savannah regions where crop water requirements typically exceed precipitation (Rockström et al., 2009). Such regions are not necessarily considered water-scarce; rather it is the intensity and timing of precipitation throughout the year and its concentration in short wet seasons which present challenges for land and water resources management. As such, these regions, especially sub-Saharan Africa, have been the focus of research on upgrading rain-fed agriculture: under improved management, the current $10-30 \%$ use of green water could increase to $50 \%$ with significant increases in yields (Falkenmark and Rockström, 2006). Such a strategy aims to reduce evaporation (unproductive green water) and increase transpiration (productive green water) through a socalled "vapour shift" (Rockström, 2003; Rockström et al., 2007).

Improvements in water productivity, or the amount of crops produced per unit input of water consumed (Cai et al., 2011), could decrease the water requirements for food production in 2050 by almost $2850 \mathrm{~km}^{3} \mathrm{yr}^{-1}$, broken down into $725 \mathrm{~km}^{3} \mathrm{yr}^{-1}$ of blue water (i.e. irrigation) and $2125 \mathrm{~km}^{3} \mathrm{yr}^{-1}$ secured through green-water resources (i.e. rain-fed agriculture) (Rockström et al., 2010). Strategies for increasing food production and reaching self-sufficiency differ based on the green- and blue- water resource potential of each country (Rockström et al., 2009). An increase in the use of blue-water resources for irrigation remains a viable option as long as it does not promote further water scarcity and does not impose damages to aquatic ecosystems or land subsidence. The expansion of rain-fed agriculture into native terrestrial ecosystems remains another option for countries that could significantly expand green-water resources for food production, although not without affecting biodiversity and precipitation recycling while increasing local runoff. Virtual water imports, or the import of water virtually via agricultural products from national and international trade, are the final option for countries that are already chronically blue- and green-water-short (e.g. Jordan, Israel, Pakistan, Iraq) (Rockström et al., 2009), and a strategy which has been under scrutiny in order to qualify water savings from trade (Dalin et al., 2012; Hoekstra and Mekonnen, 2012). 


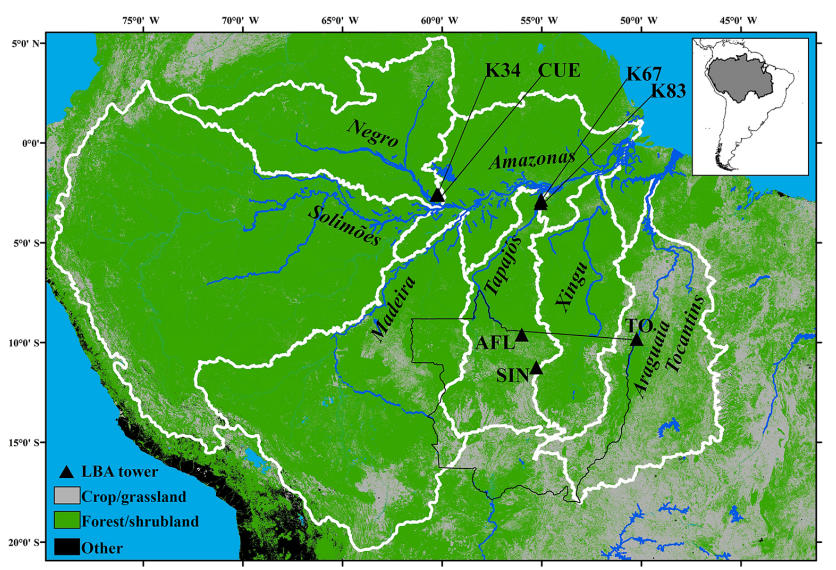

Figure 1. The Amazon Basin of South America with its main river basins (ANA, 2015), eddy covariance tower network from the Large-Scale Biosphere-Atmosphere Project in Amazonia (Table 2) (Keller et al., 2004) and aggregated land uses as classified by the ESA GlobCover 2009 Project (ESA, 2010; ${ }^{\circ}$ ESA 2010 and UCLouvain), and the political divide of the Brazilian state of Mato Grosso at the agricultural frontier of south-eastern Amazonia.

\section{Land use change as a driver of green- and blue-water trade-offs in Amazonia}

\subsection{Brazil's agricultural frontier of south-eastern Amazonia}

An important portion of Brazil's economic future is focused on the continuous increase of production for export of soybean and maize feed for cattle, and beef (MAPA, 2013), which itself relies on south-eastern Amazonia's strongly seasonal agricultural frontier, with semi-arid conditions during extended periods (Fig. 1). This frontier is located in the headwaters of main tributaries of the Amazon River, in which fisheries, navigation, and hydroelectric projects are important downstream blue-water users (Castello and Macedo, 2016). For example, the $176000 \mathrm{~km}^{2}$ upper Xingu River Basin of Mato Grosso contains over 22000 springs feeding the $510000 \mathrm{~km}^{2}$ Xingu Basin (Fig. 1) (Velasquez and Bernasconi, 2010; Macedo et al., 2013) and may soon be home to the future Belo Monte dam, which will require significant amounts of blue water to operate (Stickler et al., 2013). For such a major production centre for commodities, increases in agricultural production will need to consider green- and blue-water trade-offs from possible production pathways such as expansion into natural ecosystems, expansion into pastureland, or intensification into current land, along with additional irrigation as insurance for dry spells and drought years. The additional water vapour supply from irrigation as well as other upstream water bodies (e.g. small farm dams) represents an important planning consideration for the regional water cycle. While much of previous research has focused on regional temperatures and greenhouse gases (Oliveira et al., 2013), precipitation recycling (Stickler et al., 2013; Bagley et al., 2014), river discharge (Coe et al., 2011, 2009; Panday et al., 2015), and impacts to biodiversity (Chaplin-Kramer et al., 2015), detailed modelling studies on how potential increases in regional water vapour flows from irrigation may impact the water cycle in Amazonia are still lacking despite the current state of knowledge on atmospheric feedbacks from land use change. We explore these implications by focusing exclusively on greenand blue-water trade-offs in the region.

\subsection{Controls on evapotranspiration in Amazonia}

The Amazon Basin is abundant in both green and blue water (see Supplement), whose trade-offs result from environmental and biological controls of ET. Environmental controls follow a precipitation gradient that declines from north to south over the $0-11^{\circ} \mathrm{S}$ latitudinal band (Manaus to Sinop in Table 2, Fig. 1). In equatorial Amazonia (e.g. Manaus, Santarem), ET seasonality is primarily driven by radiation but is also driven by morning fog, especially in the wet season (Anber et al., 2015). The dry season occurs later in the calendar year (July-November), when increasing solar radiation coincides with limited cloud cover, favouring photosynthesis and increasing ET to more than $100 \mathrm{~mm}^{\text {month }}{ }^{-1}$ (Restrepo-Coupe et al., 2013; Christoffersen et al., 2014). In equatorial Amazonia, latent heat flux is correlated to net radiation $\left(R^{2}=0.53\right)$, suggesting that available energy is a strong control on ET within the latitudinal band (RestrepoCoupe et al., 2013). With little or no soil moisture stress affecting the productivity of broadleaf evergreen forests, ET in equatorial Amazonia is only mildly seasonal as green-water stocks remain largely available for ecosystems to consume all year round.

In contrast, ET in southern Amazonia is strongly seasonal. Remote-sensing observations from MOD16 (2000-2009) for the Amazon-Cerrado transition forest showed a forest-wide ET of $65 \mathrm{~mm} \mathrm{month}^{-1}$ for August periods, only $60 \%$ of rainy-season ET values of $105-115 \mathrm{~mm} \mathrm{month}^{-1}$ between January and April (Lathuillière et al., 2012). Future increases in regional temperatures could lead to an overall basin-wide increase in ET due to an increase in potential ET, limited, however, by regional differences in soil moisture availability, as well as groundwater reserves, which can be deeper than $20 \mathrm{~m}$ in south-eastern Amazonia (Pokhrel et al., 2014).

Biological controls on ET have been shown to occur in southern Amazonia's transition forest where high vapour pressure deficit in the dry season can trigger stomatal closure and allow forest ecosystems to conserve water in waterlimited conditions (Costa et al., 2010). Access to green water by deeply rooted trees has been suggested as a drought resilience mechanism for forest ecosystems in the region, with roots accessing soil moisture over $8 \mathrm{~m}$ deep (Nepstad et al., 1994; Davidson et al., 2011). Deeply rooted trees help sustain ET over southern Amazonia's dry season (Coe et al., 2009, 
2011; Lathuillière et al., 2012; Christoffersen et al., 2014; Biudes et al., 2015; Panday et al., 2015; Silvério et al., 2015; Vourlitis et al., 2015) and will likely become more important with increased air temperatures (Pokhrel et al., 2014). As such, land use change resulting in the replacement of forest by more shallow-rooted pasture grasses or cropland reduces the amount of accessible green water and vapour flows to the atmosphere.

Given these well-defined processes across the basin and the important role of seasonality in the southern portion, south-eastern Amazonia appears as a region that requires special attention. The region's ET processes are waterlimited during an extended dry season. A rise in the local dry-season temperatures shows the importance of soil moisture and groundwater as important water sources for deeply rooted trees to ensure continuous water vapour flows to the atmosphere (Pokhrel et al., 2014). Its geographical importance, both as the home to Brazil's expanding agriculture and as the region upstream of the Amazon River, make it an environmentally and economically important region that is sensitive to future land use and climate changes. Green- and blue-water trade-offs will be inevitable considering the current and future land use changes which decrease green-water consumption of terrestrial ecosystems and can increase blue water through runoff.

\subsection{Land use change activity for agricultural production}

Brazil's internal colonization driven by the Agrarian reform of the 1960s brought intensive agricultural activity to the Amazon and Cerrado regions. The 1980s and 1990s saw the expansion of settlements in the region, starting with cattle ranching, later followed by soybean production, both of which created economic activity that also required road building and ever-increasing mechanization of deforestation and agriculture (Fearnside, 2001, 2005; Morton et al., 2006; Rudel et al., 2009). The country's expansion of soybean production followed a south-to-north progression into the Cerrado and closer to the Amazon biome (Simon and Garagorry, 2005), today reaching south-eastern Amazonia and the state of Mato Grosso (Fig. 1). Soybean expansion has occurred either directly through a forest-to-cropland conversion or indirectly through a pasture transition (Macedo et al., 2012; Spera et al., 2014; Silvério et al., 2015), which has displaced pasture further north into the Amazon (Barona et al., 2010).

The state of Mato Grosso (Fig. 1) is a hotspot for this expanding agricultural frontier with more than a decade of documented deforestation activity (Macedo et al., 2012). In accordance with land use change practices, government policies, and private initiatives, Nepstad et al. (2014) identified three distinct phases guiding deforestation: agro-industrial expansion (pre-2004), frontier governance (2005-2008), and territorial performance (2009-present). Mato Grosso and Pará have shown the greatest rates of deforestation in Ama- zonia, with an accumulated 138289 and $137923 \mathrm{~km}^{2}$ respectively for the 1988-2014 period, and, together, contributed to $70 \%$ of total deforestation in Brazil (INPE, 2015). The Brazilian federal Forest Code is the main federal legislation controlling deforestation in Brazil. The 1965 version of the law requires a land reserve in which $80 \%$ of native vegetation must be retained on properties located in the Amazon biome, but this requirement on native vegetation retained drops to $50 \%$ for the Amazon-Cerrado transition zone and $20 \%$ for the Cerrado (Brannstrom et al., 2008; Soares-Filho et al., 2014). A new version of the Forest Code was signed in 2012, which retains the old reserve and provides new rules for illegal deforestation prior to 2008, while adding new incentives to reduce deforestation such as trade in land reserves between properties (Soares-Filho et al., 2014).

The drop in Mato Grosso's deforestation rates in the late 2000s coincided with a drop in exchange rate of the Brazilian real, which increased the opportunity costs of deforestation (Richards et al., 2012); restrictive access to credit for producers located in municipalities labelled as hotspots of deforestation; and the Soybean Moratorium (2006) and Cattle Agreement (2009), which sought to remove any suppliers from the soybean and meat supply chains that have produced on land previously cleared from forests (Macedo et al., 2012; Nepstad et al., 2014; Gibbs et al., 2015). Soybean and beef production, however, continued to grow with further internationalization of commodity markets as China imported an ever-increasing amount of soybean to meet its increasing national demand, mostly for producing animal protein (Lathuillière et al., 2014). Deforestation has been apparently on the rise since 2012 (INPE, 2015), which coincides with the implementation of the new Forest Code (Soares-Filho et al., 2014; Spracklen and Garcia-Carrera, 2015). Land use change activities have been recognized to have an effect on the local climate (Davidson et al., 2012) with emerging evidence of changes in regional and continental precipitation recycling, with south-eastern Amazonia playing an important role in the Amazon Basin (Table 3).

\subsection{Land use change effects on the water balance}

Differences in the energy balance have been observed on different landscapes across Amazonia (Table 2). Therefore, land use change from one landscape to another is expected to affect radiation partitioning, with noted impacts on the water cycle. Model simulations in south-eastern Amazonia have shown that changes in land cover affect surface albedo, while morphological (vegetation height, root depth, albedo) and physiological changes (C3 to $\mathrm{C} 4$ photosynthetic pathways) can affect the magnitude of sensible and latent heat fluxes (positively and negatively), with possible effects on surface temperature (Pongratz et al., 2006; Davidson et al., 2012; Bagley et al., 2014). Analysis of satellite information obtained for the Upper Xingu River Basin of Mato Grosso showed that forest-to-cropland and forest-to-pasture land use 
Table 2. Summary of precipitation $(P)$ partitioning into green-water (evapotranspiration, ET) and blue-water resources $(P$ minus ET) from observations in Amazonia. All values are expressed in $\mathrm{mm} \mathrm{yr}^{-1}$, with standard deviations of multi-year observations shown in brackets. Site locations are shown in Fig. 1.

\begin{tabular}{|c|c|c|c|c|c|}
\hline Location (period) & $\begin{array}{l}\text { Precipitation } \\
(P) \\
\mathrm{mm} \mathrm{yr}^{-1}(\mathrm{sd})\end{array}$ & $\begin{array}{l}\text { Green water } \\
(\mathrm{ET}) \\
\mathrm{mm} \mathrm{yr}^{-1}(\mathrm{sd})\end{array}$ & $\begin{array}{l}\text { Blue water } \\
(P-\mathrm{ET}) \\
\mathrm{mm} \mathrm{yr}^{-1}(\mathrm{sd})\end{array}$ & $\begin{array}{l}\text { ET / P } \\
\text { ratio }\end{array}$ & Reference \\
\hline $\begin{array}{l}\text { Amazon Basin } \\
(1976-1996)\end{array}$ & 2232 & 1384 & 937 & 0.62 & Costa and Foley $(1999)^{\mathrm{a}}$ \\
\hline $\begin{array}{l}\text { Amazon Basin } \\
(1986-1995)\end{array}$ & & $1370(183)$ & & & Fisher et al. (2009) ${ }^{\mathrm{a}}$ \\
\hline $\begin{array}{l}\text { Manaus - K34 } \\
(1999-2006)\end{array}$ & 2286 & 1157 & 1129 & 0.49 & da Rocha et al. (2009) \\
\hline $\begin{array}{l}\text { Manaus - CUE } \\
(1995-1996)\end{array}$ & 2089 & 1123 & 966 & 0.54 & Malhi et al. (2002) \\
\hline $\begin{array}{l}\text { Santarem - K67 } \\
(2000-2003)\end{array}$ & $2102(360)$ & $1044(12)$ & $1058(348)$ & 0.50 & $\begin{array}{l}\text { Hutyra et al. (2005); } \\
\text { da Rocha et al. (2009) }\end{array}$ \\
\hline $\begin{array}{l}\text { Santarem - K83 } \\
(2000-2001)\end{array}$ & 1811 & 1403 & 408 & 0.77 & da Rocha et al. $(2004,2009)$ \\
\hline $\begin{array}{l}\text { Banana Island - TO } \\
(2003-2006)\end{array}$ & $1692(222)$ & $1271(30)$ & $421(224)$ & 0.75 & Borma et al. (2009) \\
\hline $\begin{array}{l}\text { Alta Floresta - AF } \\
(2003-2004)\end{array}$ & 2223 & $1100(75)$ & 1123 & 0.49 & Biudes et al. (2015) \\
\hline $\begin{array}{l}\text { Sinop - SIN } \\
(2000-2006)\end{array}$ & $2137(256)$ & $965(44)$ & $1171(285)$ & 0.45 & Vourlitis et al. (2015) \\
\hline Tropical forest $\mathrm{t}^{\mathrm{c}}$ & $2096^{b}$ & $1099(12)$ & 997 & 0.52 & Lathuillière et al. (2012) \\
\hline Pasture $^{\mathrm{c}}$ & $2096^{\mathrm{b}}$ & 856 & 1240 & 0.41 & Lathuillière et al. (2012) ${ }^{\mathrm{a}}$ \\
\hline Soybean $^{\mathrm{c}}$ & & $363-540$ & & & Lathuillière et al. (2012) ${ }^{\mathrm{a}}$ \\
\hline Soybean + maize ${ }^{c}$ & & $520-852$ & & & Lathuilliere et al. $(2012)^{\mathrm{a}}$ \\
\hline
\end{tabular}

transitions in the 2000s decreased ET (32 and 24\%), increased sensible heat flux ( 6 and $9 \%$ ), and increased surface temperature up to $6.4^{\circ} \mathrm{C}$ (Silvério et al., 2015). In the Amazon Basin, deforestation reduced ET by $5 \%$, increased sensible heat flux by $2 \%$, and decreased precipitation by $6 \%$ in the dry season (Bagley et al., 2014), all of which were exacerbated in drought years $(6,4$, and $6 \%$ respectively). Morphological differences in the root infrastructure can make green water more accessible to maintain ET processes during the dry season (Nepstad et al., 1994; Lathuillière et al., 2012).

The above changes in surface energy balance affect the partitioning of precipitation into blue and green water as quantified by runoff and ET. Field studies in south-eastern Amazonia have shown that soybean watersheds can have water yields up to 4 times greater than forested watersheds (Hayhoe et al., 2011; Dias et al., 2015). Coe et al. (2009) simulated runoff in the Amazon Basin through a coupled land-atmosphere and climate change numerical model. Most tested river basins exhibited an increase in discharge for 2000 and 2050 when compared to potential natural vegetation, even in a restrictive deforestation governance scenario. The Tocantins and Madeira rivers (Fig. 1) saw discharges increase from 26 and $7 \%$ in 2000 to 18 and $32 \%$ for 2050 respectively (Coe et al., 2009). Similarly, discharges of the Xingu and Araguaia rivers have increased 6\% (1970 to 2000s) and $25 \%$ (1970 to 1990) primarily due to deforestation and climate (Coe et al., 2011; Panday et al., 2015).

Local changes in land cover also change vapour supply to the atmosphere, which can reduce regional precipitation and, indirectly, river discharge in the basin (Coe et al., 2009, 2011; Ellison et al., 2012). The Amazon Basin is the source of moisture to a precipitationshed that provides subtropical rainfall as far south as the La Plata Basin through the South American Low-Level Jet (Marengo, 2006; Keys et al., 2012). Vegetative surfaces promote additional vapour inputs into air masses that result in precipitation in downwind areas (Spracklen et al., 2012), with evaporated water sources contributing to continental precipitation less than $2000 \mathrm{~km}$ away (van der Ent and Savenije, 2011). Results for the 20002009 period show a $10 \%$ drop in the contributions of forests to total water vapour flows to the atmosphere (a decrease of $119 \mathrm{~km}^{3}$ from $593 \mathrm{~km}^{3} \mathrm{yr}^{-1}$ to $474 \mathrm{~km}^{3} \mathrm{yr}^{-1}$ ) due to a shift of green water use from natural ecosystems to agricultural production in the state of Mato Grosso (Lathuillière et al., 
2012). In the same time period, the Upper Xingu Basin experienced a $35 \mathrm{~km}^{3} \mathrm{yr}^{-1}$ ET drop due to land use change (Silvério et al., 2015). This reduction in vapour supply to the atmosphere can also affect river discharges and hydropower generation within the basin (Stickler et al., 2013).

Local land cover change compounds the effects of interannual variability effects of regional precipitation in the basin. While pluvial and drought years affected regional precipitation regimes, local deforestation impacts on precipitation were at least as important as regional effects (Bagley et al., 2014). Areas of deforestation showed up to a $20 \%$ decrease in precipitation during the dry months of drought years (Bagley et al., 2014) with interconnected regions of precipitation source, or precipitationshed (e.g. central and southern Amazonia), to distant sinks (north-western Amazonia). On a local scale, precipitation in the Xingu River Basin was found to be sensitive to potential future deforestation both inside the confines of the basin and in the rest of the Amazon forest (Stickler et al., 2013). This means that land cover change in one region can greatly affect precipitation in addition to local recycling, such as in south and central Amazonia (Spracklen et al., 2012; Bagley et al., 2014). Drought years were found to increase recycled evaporation from 67 to $74 \%$ in the dry months of south-eastern Amazonia (Bagley et al., 2014), indicating that atmospheric water demand can be met, in part, from regional sources.

\subsection{Linking vapour supply to precipitation and terrestrial ecosystems}

A diminished vapour supply to the atmosphere as a result of land use change can affect regional precipitation patterns, which can in turn impact ecosystem processes and services in the region. Precipitation has been declining in Amazonia in recent years (Hilker et al., 2014). Analysis of 280 meteorological stations across the basin showed a decline in precipitation of $5.3 \pm 0.7 \mathrm{~mm} \mathrm{yr}^{-1}$ for the 1996-2005 period, and an increase to $7.8 \pm 1.6 \mathrm{~mm} \mathrm{yr}^{-1}$ in areas with denser tree cover (Brando et al., 2010). More recent analysis of satellite imagery confirmed a $17-30 \%$ decline in precipitation over the greater portion of landscapes of the Amazon region for the 2000-2012 period, especially in eastern and south-eastern Amazonia, which showed a $25 \%$ decline in precipitation for the period (Hilker et al., 2014).

In contrast, the Cerrado did not show any decline in precipitation between 2002 and 2010, but the biome did see an average increase in ET of $51 \pm 15 \mathrm{~mm} \mathrm{yr}^{-1}$ (Oliveira et al., 2014). The above results are in line with a review of 26 studies linking deforestation to reductions in precipitation (Marengo, 2006) as well as 96 simulations (Spracklen and Garcia-Carrera, 2015). Deforestation is also known to increase the length of the dry season, particularly in southern Amazonia, with possible changes in the onset of the wet season (Costa and Pires, 2010). Since 1979, the end of the dry season in southern Amazonia has been delayed by $4.5 \pm 2.0$ days per decade, with serious implications on the integrity of the tropical forest ecosystem should the dry season length continue to increase this Century (Fu et al., 2013).

Deforestation in a business-as-usual scenario could lead to declines in precipitation by $8 \pm 4 \%$ in the Amazon Basin, which was greater than annual natural variability of $5 \%$ (Spracklen and Garcia-Carrera, 2015). Southern and central Amazonia regions can be considered a hotspot for changes in recycled precipitation. This is due to water limitations on ET (Biudes et al., 2015; Vourlitis et al., 2015), high precipitation recycling ratios, and the extended dry season, especially in the south-south-eastern region. Declines in precipitation can be accompanied by reductions in vegetation greenness, which further impacts the availability of green-water resources and the local water balance (Hilker et al., 2014). Reduced precipitation diminishes the amount of green water available for terrestrial ecosystems, with a possible impact on net primary production. Results of a 5-year rainfall exclusion experiment (near CUE, Santarem, Fig. 1) showed an increase in tree mortality of $5.7 \% \mathrm{yr}^{-1}$ compared to $2.5 \% \mathrm{yr}^{-1}$ for the control plot, along with a decrease in aboveground live biomass by $25 \%$ and an increasing difference in wood production between experimental and control plots by up to $58 \%$ (Nepstad et al., 2002; Brando et al., 2008).

\section{Including cropland irrigation in future modelling}

Studies to date have considered land-atmosphere coupling in relation to agricultural expansion that is exclusively reliant on green water. However, on-farm water management can supply further water vapour to local precipitationsheds through irrigation, which also needs to be considered in future modelling work. Such consideration calls for further protection of natural ecosystems, especially in southern and south-eastern Amazonia following climate predictions and future reductions in local regional precipitation (Coe et al., 2013). Simulations of Amazonia's possible conditions in 2050 including climate, deforestation, and atmospheric feedbacks show an overall decline in aboveground biomass and agricultural yields (pasture and soybean), although the interaction of these effects is unclear at high resolution in southern Amazonia (Oliveira et al., 2013): effects from changes to climate $\left(+2.3^{\circ} \mathrm{C}\right)$ and atmospheric $\mathrm{CO}_{2}$ concentrations $(590 \mathrm{ppm})$ shortened the development cycle of soybean. This fertilization effect, however, can greatly vary based on precipitation: reduced rainfall in southern Mato Grosso's Cerrado region likely affected soybean yields negatively (Oliveira et al., 2013). Results from such models should be confirmed with higher-resolution measurements, and consideration should be given to irrigation as a viable future practice to maintain higher agricultural yields while ensuring continued water vapour supply to the atmosphere. 
To illustrate this effect, we provide an estimate of irrigation vapour flows that would result from blue-water consumptive use of cropland and pasture in south-eastern Amazonia. By modelling crop water requirements combining Food and Agriculture Organization guidelines (Allen et al., 1998) with meteorological data from stations located across a north-to-south gradient in Mato Grosso (sensu Lathuillière et al., 2012), we calculate these additional water vapour flows assuming crop water requirements are fully met. We include an estimate for changes in pasture ET that would result from irrigation, assuming that $200 \mathrm{~mm} \mathrm{yr}^{-1}$ of irrigation is supplied to the 20-22 Mha of existing pasture in Mato Grosso alone (Fig. 2). These additional vapour flows thus represent an approximation of the amount of blue water redirected to ET that would be required under an ideal irrigation scenario for cropland and pasture.

The irrigation required for all cropland was estimated at $15-28 \mathrm{~km}^{3} \mathrm{yr}^{-1}$ during the 2000-2009 period, with higher amounts corresponding to drought periods and lower amounts related to wetter years. An additional average of $51 \mathrm{~km}^{3} \mathrm{yr}^{-1}$ of water vapour could have been generated between 2001 and 2009 if all cropland and pasture had been irrigated to meet water requirements. This additional bluewater consumption is equivalent to about $40 \%$ of the estimated $125 \mathrm{~km}^{3} \mathrm{yr}^{-1}$ loss in water vapour contributions from the forest cover reduction that occurred to create cropland and pasture (Lathuillière et al., 2012).

Impacts of expanded irrigation on the local climate and precipitationsheds need to be addressed in land-atmosphere models. Additional water vapour resulting from a blue-togreen-water transfer via irrigation under non-limiting conditions indicates that cropland alone would transfer an amount of water to the atmosphere each year equivalent to the maximum volume stored by the Itaipu dam $\left(29 \mathrm{~km}^{3}\right.$; Itaipu Binacional, 2015), currently the largest reservoir in Brazil. Considering local water scarcity, such consumption would have occurred at the expense of aquatic ecosystems and groundwater-dependent terrestrial ecosystems. Given the importance of the groundwater buffer for ecosystem resilience in south-eastern Amazonia (Pokhrel et al., 2014), it is also necessary to address how such blue-water consumption for irrigation might impact surface water and groundwater stocks and further limit ET processes.

In order to more fully consider the trade-offs between green and blue water resulting from land use change, climate change, and alterations in water management including irrigation, we consider the interacting effects of agricultural expansion into natural ecosystems in south-eastern Amazonia that contribute to decreasing ET and precipitation recycling in the broader region. We propose five possible options for land and water management for future agricultural production in the region considering the current objectives to increase agricultural production (MAPA, 2013). These options include the expansion of rain-fed agriculture into natural ecosystems (option A); the expansion of rain-fed agricul-

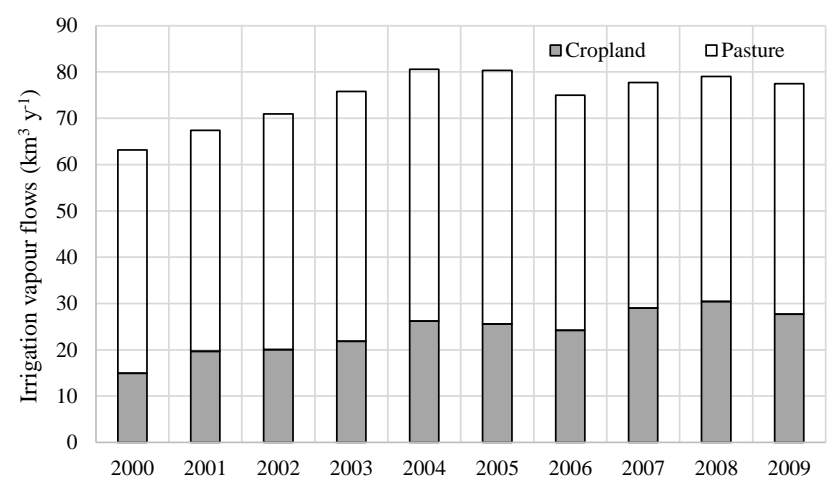

Figure 2. Annual irrigation requirements for cropland (as the sum of soybean, maize, cotton, and sugar cane) and pasture in southeastern Amazonia (Mato Grosso) for the 2000-2009 period.

ture into current pastureland (option B); improved soil water management to reduce evaporation and increase transpiration, or vapour shift (option C); rainwater harvesting (option $\mathrm{D}$ ); and the expansion of irrigation in current production (option E) (Table 3, Fig. 3).

From all the water management options proposed, expansion of rain-fed agriculture into natural ecosystems (option A), rainwater harvesting (option D), and irrigation expansion (option E) will result in trade-offs with blue-water users downstream. Expansion of rain-fed agriculture into current pasture (option B) and vapour shift (option C) will not incur such trade-offs but may still maintain precipitation recycling. Expansion of rain-fed agriculture into natural ecosystems (option A) is the only presented option that would further call for deforestation with consequences on the water cycle, as well as biodiversity and $\mathrm{CO}_{2}$ emissions. Expansion into current pasture (option B) still promotes green-water consumption through expansion by colonizing current pastureland. The improvement of yield through vapour shift (option C) is limited, however, if we only consider improvements through water consumption. Improvements in yield are likely to be more reliant on additional fertilizer inputs with possible water quality aspects. A combination of horizontal expansion of cropland into pasture and irrigation (options B and E) would considerably increase the amount of surface water and groundwater required for agriculture. A doubling of 2013 soybean production (from $23 \mathrm{Mt}$ according to IBGE, 2015) would require roughly $7.5 \mathrm{Mha}$ of pastureland to be converted to soybean, with an additional $10.5 \mathrm{~km}^{3} \mathrm{yr}^{-1}$ of blue water required for irrigation. Options C, D, and E represent intensification options with and without blue-water consumption, respectively by vapour shift, rainwater harvesting, and expansion of irrigated land. These options might be more desirable given Brazil's objectives to reduce deforestation by $80 \%$ in the Amazon by 2020 and $40 \%$ in the Cerrado compared to a 1996-2005 baseline (Galford et al., 2013). To some extent, rainwater harvesting has already taken place in the case of cattle ranching on pastureland when 
Table 3. Annual precipitation recycling ratios for the Amazon region.

\begin{tabular}{lll}
\hline Region & $\begin{array}{l}\text { Precipitation } \\
\text { recycling ratio* }\end{array}$ & Reference \\
\hline Amazon Basin & 0.25 & Eltahir and Bras (1994) \\
Amazon Basin & 0.30 & Costa and Foley (1999) \\
Amazon Basin & 0.28 & van der Ent and Savenije (2010) \\
$10^{6} \mathrm{~km}^{2}$ in NW Amazon & 0.11 & Dirmeyer and Brubaker (2007) \\
Sub-region of the Amazon biome & $0.17-0.29$ & Bagley et al. (2014) \\
\hline
\end{tabular}

* We use the definition by van der Ent et al. (2010) as the amount of regional precipitation sourced within an area of interest.

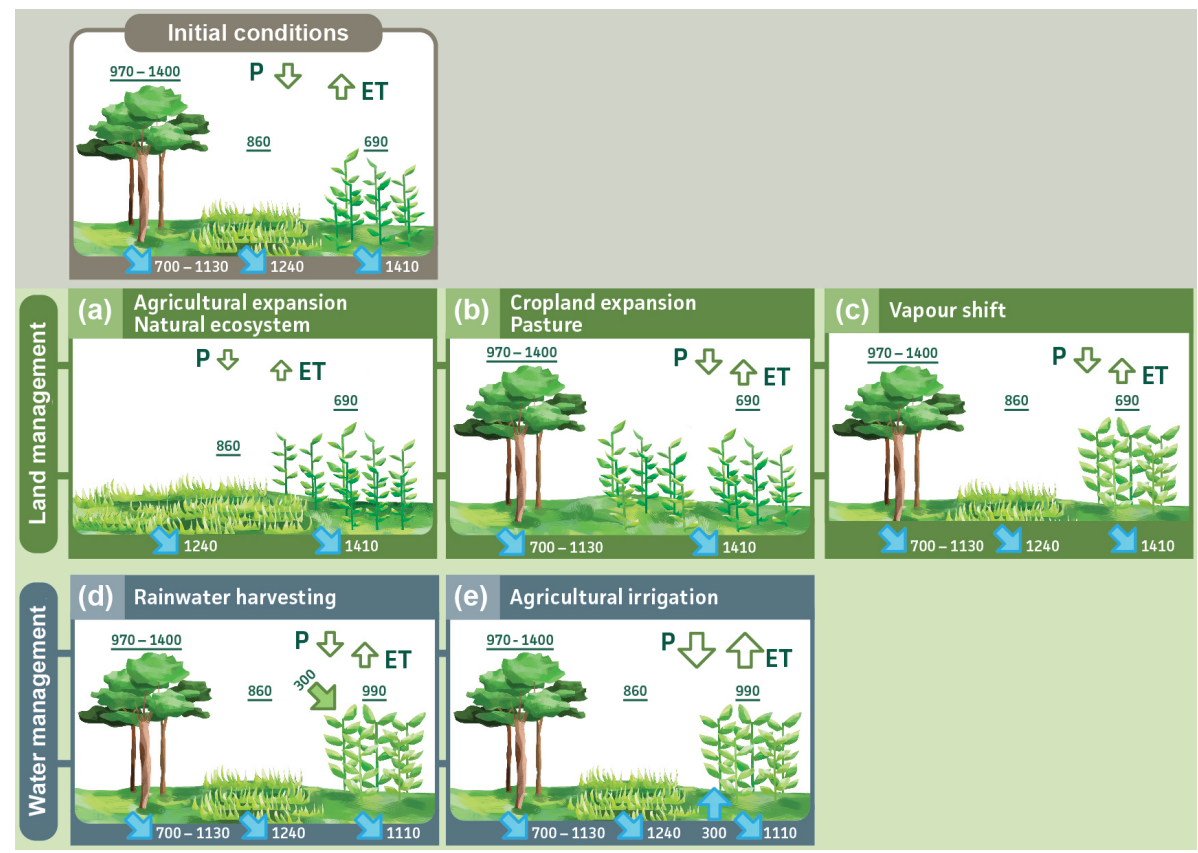

Figure 3. Graphical representation of land and water management options listed in Table 3, with values representing typical evapotranspiration (underlined numbers, $\mathrm{mm} \mathrm{yr}^{-1}$ ) and runoff (blue arrows pointing downwards, $\mathrm{mm} \mathrm{yr}^{-1}$ ) assuming $2000 \mathrm{~mm} \mathrm{yr}^{-1}$ of $\mathrm{precipitation}$. The downward-facing green arrow (box D) and upward-facing blue arrow (box E) represent $300 \mathrm{~mm} \mathrm{yr}^{-1}$ of rainwater harvesting and irrigation respectively.

small, often rain-fed farm dams are used to supply cattle with drinking water. In 2007, about 10000 such dams were accounted for in the Upper Xingu Basin of Mato Grosso (Macedo et al., 2013). Considering an average farm dam size of $0.25 \mathrm{~km}^{2}$ and a volume-to-area relationship similar to the state of Goiás described in Rodrigues et al. (2012), we estimate a total small-farm-dam volume of $6 \mathrm{~km}^{3}$, of which $2.4 \mathrm{~km}^{3}$ may be directly evaporated according to small-dam evaporation estimates (Baillie, 2008). Such additional water vapour supply to the atmosphere should also be accounted for in future models. The case of irrigation expansion (option E) has the potential to promote agricultural intensification with marginal improvements to precipitation recycling, which still needs to be proven in future research. While this option does prevent further deforestation, its impact on surface water and groundwater resources will have to be assessed to identify a win-win scenario of increased agricultural production: precipitation recycling without degradation of aquatic ecosystems.

The above-discussed options are focused exclusively on water quantity and should be accompanied by a water quality consideration adding further complexity to the abovementioned trade-offs. All described options except rainwater harvesting (option D) will likely lead to changes in surface water and groundwater quality due to additional fertilizer inputs. These consequences are still uncertain in southeastern Amazonia, with limited indication on eutrophication from agricultural land (Riskin et al., 2013). Measurements made by the Environmental Secretariat of Mato Grosso (Secretaria de Estado do Meio Ambiente, or SEMA) show phosphate concentrations in Amazon tributaries greater than $0.10 \mathrm{mg} \mathrm{L}^{-1}$ at 4 out of 14 stations in the Juruena-Arinos 
Table 4. Green- and blue-water use options to increase agricultural production in south-eastern Amazonia with possible trade-offs in water resources and regional precipitation recycling.

\begin{tabular}{|c|c|c|c|c|}
\hline Option & Strategy & $\begin{array}{l}\text { Effects on agricultural } \\
\text { production }\end{array}$ & $\begin{array}{l}\text { Effect on water resources in the } \\
\text { region }\end{array}$ & $\begin{array}{l}\text { Possible effects } \\
\text { on precipitation } \\
\text { recycling }\end{array}$ \\
\hline $\begin{array}{l}\text { A. Increase } \\
\text { green-water use } \\
\text { for agriculture }\end{array}$ & $\begin{array}{l}\text { Expansion of rain-fed agricul- } \\
\text { ture and pastureland into natu- } \\
\text { ral ecosystems }\end{array}$ & Increase production by area & $\begin{array}{l}\text { Reduce overall evapotranspira- } \\
\text { tion (ET); trade-offs expected } \\
\text { with blue-water users down- } \\
\text { stream }\end{array}$ & Reduced \\
\hline $\begin{array}{l}\text { B. Increase } \\
\text { green-water use } \\
\text { for agriculture }\end{array}$ & $\begin{array}{l}\text { Expansion of rain-fed agricul- } \\
\text { ture into pastureland }\end{array}$ & Increase production by area & $\begin{array}{l}\text { Marginal change in overall ET; } \\
\text { blue water downstream un- } \\
\text { changed }\end{array}$ & Maintained \\
\hline $\begin{array}{l}\text { C. Increase } \\
\text { green-water use } \\
\text { for agriculture }\end{array}$ & $\begin{array}{l}\text { Vapour shift from evaporation } \\
\text { to transpiration to improve pro- } \\
\text { ductive green-water use }\end{array}$ & Increase production by yield & $\begin{array}{l}\text { Improves productive green- } \\
\text { water use and yields by } \\
\text { postponing possible future } \\
\text { irrigation (blue-water sav- } \\
\text { ings); blue water downstream } \\
\text { unchanged }\end{array}$ & Maintained \\
\hline $\begin{array}{l}\text { D. Increase } \\
\text { green-water use } \\
\text { for agriculture }\end{array}$ & $\begin{array}{l}\text { Rainwater harvesting used off } \\
\text { season }\end{array}$ & Increase production by yield & $\begin{array}{l}\text { Improve green-water consump- } \\
\text { tive use in the same location } \\
\text { as precipitation; trade-offs ex- } \\
\text { pected with blue water users } \\
\text { downstream }\end{array}$ & Maintained \\
\hline $\begin{array}{l}\text { E. Increase } \\
\text { blue-water use } \\
\text { for agriculture }\end{array}$ & $\begin{array}{l}\text { Blue water used to irrigate agri- } \\
\text { culture and prevent further ex- } \\
\text { pansion into natural ecosystems }\end{array}$ & Increase production by yield & $\begin{array}{l}\text { Possible impacts on aquatic } \\
\text { ecosystems from the con- } \\
\text { sumption of surface water } \\
\text { and groundwater; trade-offs } \\
\text { expected with blue-water users } \\
\text { downstream }\end{array}$ & Increased \\
\hline
\end{tabular}

Basin (1 month between 2012 and 2014), while the Teles Pires Basin had 10 out of 12 stations exhibiting concentration above this limit (two to three times between 2012 and 2014 at seven stations) (SEMA, 2016). Concentrations of nitrate, however, were all lower than the $10 \mathrm{mg} \mathrm{L}^{-1}$ concentration limit set by the Brazilian National Environmental Council (Conselho Nacional do Meio Ambiente, or CONAMA) (SEMA, 2016).

\section{Conclusions}

This review provides a detailed assessment of precipitation partitioning of Amazonia and south-eastern Amazonia's water resources into green and blue water and considers important questions about the future of land and water management in the basin. The current state of knowledge on precipitation, ET, and discharge in the basin as well as the possible effects of land use change on the hydrological cycle create additional unknowns in a region that is expected to transform from direct human involvement in land use management or indirectly from global climate change. The field of global ecohydrology can play an important role in understanding how we can limit the impact of future economic development and land management on the hydrological cycle.

South-eastern Amazonia was identified as an important region for future land and water use planning based on the following: (1) its role in future agricultural expansion for pasture and soybean, (2) the region's reliance on water for ensuring ecological and agro-ecological functions, (3) the importance of precipitation recycling and its emerging connection to land use change which might affect other Amazon sub-basins, and (4) the potential of irrigation expansion to maintain production and prevent further encroachment of agriculture into natural ecosystems. The best land and water strategy will be one that ensures connectivity within the hydrological cycle, minimizes up- and downstream blue-water trade-offs from agricultural production and maintains precipitation recycling in the region to prevent future degradation of natural ecosystems. Policy options should consider a combination of expansion of soybean into pastureland as well as increases in rain-fed agricultural yields either through an improvement in productive green-water use or through proper rainfall harvesting. Meat production in Brazil could still be increased without further deforestation, mainly by increasing beef yields (Strassburg et al., 2014), while rainwater har- 
vesting could be used to ensure supplemental irrigation in the second crop (e.g. maize or cotton) typically harvested at the onset of the dry season. This strategy has the benefit to conserve biodiversity and prevent further greenhouse gas emissions from deforestation.

Finally, such strategies have to be incorporated into greater objectives such as enforcement of the federal Forest Code, soybean and beef supply chain interventions, and land tenure issues in Brazil (Lapola et al., 2014; Nepstad et al., 2014). Global ecohydrology has a role to play in complementing these strategies to secure future water resource needs of the rapidly developing Amazon region.

\section{Data availability}

River basin shapefile information of Fig. 1 was made available through the Brazilian National Water Agency (Agência Nacional de Águas, or ANA) file repository http: //metadados.ana.gov.br/geonetwork/srv/pt/main.home, while land use information was obtained from the European Space Agency (ESA) GlobCover Portal http://due.esrin.esa. int/page_globcover.php. Information on soybean production was provided by the Instituto Brasileiro de Geografia e Estatística (IBGE), available at http://www.sidra.ibge.gov.br/ (Table 1612).

\section{The Supplement related to this article is available online at doi:10.5194/hess-20-2179-2016-supplement.}

\begin{abstract}
Acknowledgements. This review represents a contribution to "Integrating land use planning and water governance in Amazonia: Towards improving freshwater security in the agricultural frontier of Mato Grosso", a project supported by the Belmont Forum and the G8 Research Councils Freshwater Security Grant G8PJ-4373762012 through the Natural Sciences and Engineering Research Council (NSERC) to M. S. Johnson, and the National Science Foundation to M. T. Coe. Additional support was provided by the Vanier Graduate Scholarship through NSERC to M. J. Lathuillière (no. 201411DVC-347484-257696). Special thanks are owed to George Vourlitis for insightful discussions.
\end{abstract}

Edited by: S. Thompson

\section{References}

Allen, R., Pereira, L., and Raes D, S. M.: Crop evapotranspiration: guidelines for computing crop water requirements, Food and Agriculture Organization of the United Nations, Rome, 1998.

ANA (2015): GeoNetwork, available at: http://metadados.ana.gov. br/geonetwork/srv/pt/main.home, last access: September 2015.
Anber, U., Gentine, P., Wang, S., and Sobel, A. H.: Fog and rain in the Amazon, P. Natl. Acad. Sci. USA, 112, 11473-11477, doi:10.1073/pnas.1505077112, 2015.

Bagley, J. E., Desai, A. R., Harding, K. J., Snyder, P. K., and Foley, J. A.: Drought and Deforestation: Has Land Cover Change Influenced Recent Precipitation Extremes in the Amazon?, J. Clim., 27, 345-361, doi:10.1175/JCLI-D-12-00369.1, 2014.

Baillie, C.: Assessment of evaporation losses and evaporation mitigation technologies for on farm water storages in Australia, Cooperative Research Center for Irrigation Futures, 2008.

Barona, E., Ramankutty, N., Hyman, G., and Coomes, O. T.: The role of pasture and soybean in deforestation of the Brazilian Amazon, Environ. Res. Lett., 5, 024002, doi:10.1088/17489326/5/2/024002, 2010.

Biggs, T. W., Scott, C. A., Gaur, A., Venot, J., Chase, T., and Lee, E.: Impacts of irrigation and anthropogenic aerosols on the water balance, heat fluxes, and surface temperature in a river basin, Water Resour. Res., 44, W12415, doi:10.1029/2008WR006847, 2008.

Biudes, M. S., Vourlitis, G. L., Machado, N. G., Zanella de Arruda, P. H., Rodrigues Neves, G. A., Lobo, F. d. A., Usher Neale, C. M., and Nogueira, J. d. S.: Patterns of energy exchange for tropical ecosystems across a climate gradient in Mato Grosso, Brazil, Agr. Forest Meteorol., 202, 112-124, doi:10.1016/j.agrformet.2014.12.008, 2015.

Borma, L. S., da Rocha, H. R., Cabral, O. M., von Randow, C., Collicchio, E., Kurzatkowski, D., Brugger, P. J., Freitas, H., Tannus, R., Oliveira, L., Renno, C. D., and Artaxo, P.: Atmosphere and hydrological controls of the evapotranspiration over a floodplain forest in the Bananal Island region, Amazonia, J. Geophys. Res.Biogeosci., 114, G01003, doi:10.1029/2007JG000641, 2009.

Brando, P. M., Nepstad, D. C., Davidson, E. A., Trumbore, S. E., Ray, D., and Camargo, P.: Drought effects on litterfall, wood production and belowground carbon cycling in an Amazon forest: results of a throughfall reduction experiment, Philos. T. Roy. Soc. B-Biological Sciences, 363, 1839-1848, doi:10.1098/rstb.2007.0031, 2008.

Brando, P. M., Goetz, S. J., Baccini, A., Nepstad, D. C., Beck, P. S. A., and Christman, M. C.: Seasonal and interannual variability of climate and vegetation indices across the Amazon, P. Natl. Acad. Sci. USA, 107, 14685-14690, doi:10.1016/j.agrformet.2014.12.008, 2010.

Brannstrom, C., Jepson, W., Filippi, A. M., Redo, D., Xu, Z., and Ganesh, S.: Land change in the Brazilian Savanna (Cerrado), 1986-2002: Comparative analysis and implications for land-use policy, Land Use Policy, 25, 579-595, doi:10.1016/j.landusepol.2007.11.008, 2008.

Cai, X., Molden, D., Mainuddin, M., Sharma, B., Ahmad, M., and Karimi, P.: Producing more food with less water in a changing world: assessment of water productivity in 10 major river basins, Water Int., 36, 42-62, doi:10.1080/02508060.2011.542403, 2011.

Castello, L. and Macedo, M. N.: Large-scale degradation of Amazonian freshwater ecosystems, Global Change Biol., 22, 990-1007, doi:10.1111/gcb.13173, 2016.

Chaplin-Kramer, R., Sharp, R. P., Mandle, L., Sim, S., Johnson, J., Butnar, I., Mila i Canals, L., Eichelberger, B. A., Ramler, I., Mueller, C., McLachlan, N., Yousefi, A., King, H., and Kareiva, P. M.: Spatial patterns of agricultural expansion determine im- 
pacts on biodiversity and carbon storage, P. Natl. Acad. Sci. USA, 112, 7402-7407, doi:10.1073/pnas.1406485112, 2015.

Christoffersen, B. O., Restrepo-Coupe, N., Arain, M. A., Baker, I. T., Cestaro, B. P., Ciais, P., Fisher, J. B., Galbraith, D., Guan, X., Gulden, L., van den Hurk, B., Ichii, K., Imbuzeiro, H., Jain, A., Levine, N., Miguez-Machor, G., Poulter, B., Roberti, D. R., Sakaguchi, K., Sahoo, A., Schaefer, K., Shi, M., Verbeeck, H., Yang, Z., Araujo, A. C., Kruijt, B., Manzi, A. O., da Rocha, H. R., von Randow, C., Muza, M. N., Borak, J., Costa, M. H., Goncalves de Goncalves, L. G., Zeng, X., and Saleska, S. R.: Mechanisms of water supply and vegetation demand govern the seasonality and magnitude of evapotranspiration in Amazonia and Cerrado, Agr. Forest Meteorol., 191, 3350, doi:10.1016/j.agrformet.2014.02.008, 2014.

Coe, M. T., Costa, M. H., and Soares-Filho, B.: The influence of historical and potential future deforestation on the stream flow of the Amazon River - Land surface processes and atmospheric feedbacks, J. Hydrol., 369, 165-174, doi:10.1016/j.jhydrol.2009.02.043, 2009.

Coe, M. T., Latrubesse, E. M., Ferreira, M. E., and Amsler, M. L.: The effects of deforestation and climate variability on the streamflow of the Araguaia River, Brazil, Biogeochemistry, 105, 119 131, doi:10.1007/s10533-011-9582-2, 2011.

Coe, M. T., Marthews, T. R., Costa, M. H., Galbraith, D. R., Greenglass, N. L., Imbuzeiro, H. M. A., Levine, N. M., Malhi, Y., Moorcroft, P. R., Muza, M. N., Powell, T. L., Saleska, S. R., Solorzano, L. A., and Wang, J.: Deforestation and climate feedbacks threaten the ecological integrity of South-Southeastern Amazonia, Philos. T. Roy. Soc. B-Biological Sciences, 368, 20120155, doi:10.1016/j.jhydrol.2009.02.043, 2013.

Costa, M. and Foley, J.: Trends in the hydrologic cycle of the Amazon basin, J. Geophys. Res.-Atmos., 104, 14189-14198, doi:10.1029/1998JD200126, 1999.

Costa, M. H. and Pires, G. F.: Effects of Amazon and Central Brazil deforestation scenarios on the duration of the dry season in the arc of deforestation, Int. J. Climatol., 30, 1970-1979, doi:10.1002/joc.2048, 2010.

Costa, M. H., Biajoli, M. C., Sanches, L., Malhado, A. C. M., Hutyra, L. R., da Rocha, H. R., Aguiar, R. G., and de Araujo, A. C.: Atmospheric versus vegetation controls of Amazonian tropical rain forest evapotranspiration: Are the wet and seasonally dry rain forests any different?, J. Geophys. Res.-Biogeosci., 115, G04021, doi:10.1029/2009JG001179, 2010.

da Rocha, H. R., Goulden, M. L., Miller, S. D., Menton, M. C., Pinto, L. D. V. O., de Freitas, H. C., and Figueira, A. M. E. S.: Seasonality of water and heat fluxes over a tropical forest in eastern Amazonia, Ecol. Appl., 14, S22-S32, doi:10.1890/02-6001, 2004.

da Rocha, H. R., Manzi, A. O., Cabral, O. M., Miller, S. D., Goulden, M. L., Saleska, S. R., Coupe, N. R., Wofsy, S. C., Borma, L. S., Artaxo, P., Vourlitis, G., Nogueira, J. S., Cardoso, F. L., Nobre, A. D., Kruijt, B., Freitas, H. C., von Randow, C., Aguiar, R. G., and Maia, J. F.: Patterns of water and heat flux across a biome gradient from tropical forest to savanna in Brazil, J. Geophys. Res.-Biogeosci., 114, G00B12, doi:10.1029/2007JG000640, 2009.

Dalin, C.: Evolution of the global virtual water trade network, P. Natl. Acad. Sci. USA, 109, 5989-5994, doi:10.1073/pnas.1203176109, 2012.
Davidson, E., Lefebvre, P. A., Brando, P. M., Ray, D. M., Trumbore, S. E., Solorzano, L. A., Ferreira, J. N., Bustamante, M. M. d. C., and Nepstad, D. C.: Carbon Inputs and Water Uptake in Deep Soils of an Eastern Amazon Forest, For. Sci., 57, 51-58, 2011.

Davidson, E. A., de Araujo, A. C., Artaxo, P., Balch, J. K., Brown, I. F., Bustamante, M. M. C., Coe, M. T., DeFries, R. S., Keller, M., Longo, M., Munger, J. W., Schroeder, W., Soares-Filho, B. S., Souza Jr., C. M., and Wofsy, S. C.: The Amazon basin in transition, Nature, 481, 321-328, doi:10.1038/nature10717, 2012.

Dias, L. C. P., Macedo, M. N., Costa, M. H., Coe, M. T., and Neill, C.: Effects of land cover change on evapotranspiration and streamflow of small catchments in the Upper Xingu River Basin, Central Brazil, J. Hydrol.: Regional Studies, 4, 108-122, doi:10.1016/j.ejrh.2015.05.010, 2015.

Dirmeyer, P. A. and Brubaker, K. L.: Characterization of the global hydrologic cycle from a back-trajectory analysis of atmospheric water vapor, J. Hydrometeorol., 8, 20-37, doi:10.1002/eco.1505, 2007.

Dolman, A. J., Miralles, D. G., and de Jeu, R. A. M.: Fifty years since Monteith's 1965 seminal paper: the emergence of global ecohydrology, Ecohydrology, 7, 897-902, doi:10.1002/eco.1505, 2014.

Ellison, D., Futter, M. N., and Bishop, K.: On the forest cover-water yield debate: from demand- to supply-side thinking, Global Change Biol., 18, 806-820, doi:10.1111/j.13652486.2011.02589.x, 2012.

Eltahir, E. and Bras, R.: Precipitation Recycling in the Amazon Basin, Q. J. Roy. Meteorol. Soc., 120, 861-880, 1994.

ESA, GlobCover Project: GlobCover 2009 (Global Land Cover Map): available at: http://due.esrin.esa.int/page_globcover.php (last access: September 2015), 2009.

Falkenmark, M. and Rockström, J.: Balancing water for humans and nature: the new approach in ecohydrology, Earthscan, London, UK, 2004.

Falkenmark, M. and Rockström, J.: The new blue and green water paradigm: Breaking new ground for water resources planning and management, Journal of Water Resources Planning and Management-Asce, 132, 129-132, doi:10.1061/(ASCE)07339496(2006)132:3(129), 2006.

Fearnside, P. M.: Soybean cultivation as a threat to the environment in Brazil, Environ. Conserv., 28, 23-38, doi:10.1017/S0376892901000030, 2001.

Fearnside, P. M.: Deforestation in Brazilian Amazonia: History, rates, and consequences, Conserv. Biol., 19, 680-688, doi:10.1111/j.1523-1739.2005.00697.x, 2005.

Fisher, J. B., Malhi, Y., Bonal, D., Da Rocha, H. R., De Araujo, A. C., Gamo, M., Goulden, M. L., Hirano, T., Huete, A. R., Kondo, H., Kumagai, T., Loescher, H. W., Miller, S., Nobre, A. D., Nouvellon, Y., Oberbauer, S. F., Panuthai, S., Roupsard, O., Saleska, S., Tanaka, K., Tanaka, N., Tu, K. P., and Von Randow, C.: The land-atmosphere water flux in the tropics, Global Change Biol., 15, 2694-2714, doi:10.1111/j.1365-2486.2008.01813.x, 2009.

Fu, R., Yin, L., Li, W., Arias, P. A., Dickinson, R. E., Huang, L., Chakraborty, S., Fernandes, K., Liebmann, B., Fisher, R., and Myneni, R. B.: Increased dry-season length over southern Amazonia in recent decades and its implication for future climate projection, P. Natl. Acad. Sci. USA, 110, 18110-18115, doi:10.1073/pnas.1302584110, 2013. 
Galford, G. L., Soares-Filho, B., and Cerri, C. E. P.: Prospects for land-use sustainability on the agricultural frontier of the Brazilian Amazon, Philos. T. Roy. Soc. B-Biological Sciences, 368, 20120171, doi:10.1098/rstb.2012.0171, 2013.

Gerten, D., Hoff, H., Bondeau, A., Lucht, W., Smith, P., and Zaehle, S.: Contemporary "green" water flows: Simulations with a dynamic global vegetation and water balance model, Phys. Chem. Earth, 30, 334-338, doi:10.1016/j.pce.2005.06.002, 2005.

Gibbs, H. K., Rausch, L., Munger, J., Schelly, I., Morton, D. C., Noojipady, P., Soares-Filho, B., Barreto, P., Micol, L., and Walker, N. F.: Brazil's Soy Moratorium, Science, 347, 377-378, doi:10.1126/science.aaa0181, 2015.

Gordon, L. J., Steffen, W., Jonsson, B. F., Folke, C., Falkenmark, M., and Johannessen, A: Human Modification of global water vapor flows from the land surface, P. Natl. Acad. Sci. USA, 102, 7612-7617, doi:10.1073/pnas.0500208102, 2005.

Hayhoe, S. J., Neill, C., Porder, S., McHorney, R., Lefebvre, P., Coe, M. T., Elsenbeer, H., and Krusche, A. V.: Conversion to soy on the Amazonian agricultural frontier increases streamflow without affecting stormflow dynamics, Global Change Biol., 17, 18211833, doi:10.1111/j.1365-2486.2011.02392.x, 2011.

Hilker, T., Lyapustin, A. I., Tucker, C. J., Hall, F. G., Myneni, R. B., Wang, Y., Bi, J., de Moura, Y. M., and Sellers, P. J.: Vegetation dynamics and rainfall sensitivity of the Amazon, P. Natl. Acad. Sci. USA, 111, 16041-16046, doi:10.1073/pnas.1404870111, 2014.

Hoekstra, A. Y. and Mekonnen, M. M.: The water footprint of humanity, P. Natl. Acad. Sci. USA, 109, 3232-3237, doi:10.1073/pnas.1109936109, 2012.

Hoff, H.: The global water challenge - Modeling green and blue water Preface, J. Hydrol., 384, 175-176, doi:10.1016/j.jhydrol.2010.02.027, 2010.

Hutyra, L., Munger, J., Nobre, C., Saleska, S., Vieira, S., and Wofsy, S.: Climatic variability and vegetation vulnerability in Amazonia, Geophys. Res. Lett., 32, L24712, doi:10.1029/2005GL024981, 2005.

IBGE: Banco de dados agregados: available at: http://www.sidra. ibge.gov.br/, 2015.

INPE: Projeto PRODES, Monitoramente da floresta amazonica brasileira por satelite, available at: http://www.obt.inpe.br/ prodes/index.php, last access: March 2015.

Itaipu Binacional: Itaipu em números, available at: https://www. itaipu.gov.br/sala-de-imprensa/itaipu-em-numeros, last access: December 2015.

Jung, M., Reichstein, M., Ciais, P., Seneviratne, S. I., Sheffield, J., Goulden, M. L., Bonan, G., Cescatti, A., Chen, J., de Jeu, R., Dolman, A. J., Eugster, W., Gerten, D., Gianelle, D., Gobron, N., Heinke, J., Kimball, J., Law, B. E., Montagnani, L., Mu, Q., Mueller, B., Oleson, K., Papale, D., Richardson, A. D., Roupsard, O., Running, S., Tomelleri, E., Viovy, N., Weber, U., Williams, C., Wood, E., Zaehle, S., and Zhang, K.: Recent decline in the global land evapotranspiration trend due to limited moisture supply, Nature, 467, 951-954, doi:10.1038/nature09396, 2009.

Karlberg, L., Rockström, J., and Falkenmark, M.: Water resource implications of upgrading rainfed agriculture - focus of green and blue water trade-offs, in: Rainfed agriculture: unlocking the potential, edited by: Wani, S. P., Rockström, J., and Oweis, T., CAB International, UK, 44-53, 2009.
Keller, M., Alencar, A., Asner, G., Braswell, B., Bustamante, M., Davidson, E., Feldpausch, T., Fernandes, E., Goulden, M., Kabat, P., Kruijt, B., Luizao, F., Miller, S., Markewitz, D., Nobre, A., Nobre, C., Priante, N., da Rocha, H., Dias, P., von Randow, C., and Vourlitis, G.: Ecological research in the largescale biosphere-atmosphere experiment in Amazonia: Early results, Ecol. Appl., 14, S3-S16, doi:10.1890/03-6003, 2004.

Keys, P. W., van der Ent, R. J., Gordon, L. J., Hoff, H., Nikoli, R., and Savenije, H. H. G.: Analyzing precipitationsheds to understand the vulnerability of rainfall dependent regions, Biogeosciences, 9, 733-746, doi:10.5194/bg-9-733-2012, 2012.

Lapola, D. M., Martinelli, L. A., Peres, C. A., Ometto, J. P. H. B., Ferreira, M. E., Nobre, C. A., Aguiar, A. P. D., Bustamante, M. M. C., Cardoso, M. F., Costa, M. H., Joly, C. A., Leite, C. C., Moutinho, P., Sampaio, G., Strassburg, B. B. N., and Vieira, I. C. G.: Pervasive transition of the Brazilian land-use system, Nature Clim. Change, 4, 27-35, doi:10.1038/NCLIMATE2056, 2014.

Lathuillière, M. J., Johnson, M. S., and Donner, S. D.: Water use by terrestrial ecosystems: temporal variability in rainforest and agricultural contributions to evapotranspiration in Mato Grosso, Brazil, Environ. Res. Lett., 7, 024024, doi:10.1088/17489326/7/2/024024, 2012.

Lathuillière, M. J., Johnson, M. S., Galford, G. L., and Couto, E. G.: Environmental footprints show China and Europe's evolving resource appropriation for soybean production in Mato Grosso, Brazil, Environ. Res. Lett., 9, 074001, doi:10.1088/17489326/9/7/074001, 2014.

Macedo, M. N., DeFries, R. S., Morton, D. C., Stickler, C. M., Galford, G. L., and Shimabukuro, Y. E.: Decoupling of deforestation and soy production in the southern Amazon during the late 2000s, P. Natl. Acad. Sci. USA, 109, 1341-1346, doi:10.1073/pnas.1111374109, 2012.

Macedo, M. N., Coe, M. T., DeFries, R., Uriarte, M., Brando, P. M., Neill, C., and Walker, W. S.: Land-use-driven stream warming in Southeastern Amazonia, Philos. T. Roy. Soc. B-Biological Sciences, 368, 20120153, doi:10.1098/rstb.2012.0153, 2013.

Malhi, Y., Pegoraro, E., Nobre, A., Pereira, M., Grace, J., Culf, A., and Clement, R.: Energy and water dynamics of a central Amazonian rain forest, J. Geophys. Res.-Atmos., 107, 8061, doi:10.1029/2001JD000623, 2002.

Mao, J., Fu, W., Shi, X., Ricciuto, D. M., Fisher, J. B., Dickinson, R. E., Wei, Y., Shem, W., Piao, S., Wang, K., Schwalm, C. R., Tian, H., Mu, M., Arain, A., Ciais, P., Cook, R., Dai, Y., Hayes, D., Hoffman, F. M., Huang, M., Huang, S., Huntzinger, D. N., Ito, A., Jain, A., King, A. W., Lei, H., Lu, C., Michalak, A. M., Parazoo, N., Peng, C., Peng, S., Poulter, B., Schaefer, K., Jafarov, E., Thornton, P. E., Wang, W., Zeng, N., Zeng, Z., Zhao, F., Zhu, Q., and Zhu, Z.: Disentangling climatic and anthropogenic controls on global terrestrial evapotranspiration trends, Environ. Res. Lett., 10, 094008, doi:10.1088/1748-9326/10/9/094008, 2015.

MAPA: Projeções do agronegócio: Brasil 2012/2013 a 2022/2023, Projeções de longo prazo, Ministério da Agricultura, Pecuaria e Abastecimento, Brasilia, DF, 2013.

Marengo, J. A.: On the hydrological cycle of the Amazon basin; a historical review and current state-of-the-art, Revista Brasileira de Meteorologia, 21, 1-19, 2006.

Matyas, C. and Sun, G.: Forests in a water limited world under climate change, Environ. Res. Lett., 9, 085001, doi:10.1088/17489326/9/8/085001, 2014. 
Morton, D. C., DeFries, R. S., Shimabukuro, Y. E., Anderson, L. O., Arai, E., Espirito-Santo, F. d. B., Freitas, R., and Morisette, J.: Cropland expansion changes deforestation dynamics in the southern Brazilian Amazon, P. Natl. Acad. Sci. USA, 103, 14637-14641, doi:10.1073/pnas.0606377103, 2006.

Nepstad, D. C., Decarvalho, C. R., Davidson, E. A., Jipp, P. H., Lefebvre, P. A., Negreiros, G. H., Dasilva, E. D., Stone, T. A., Trumbore, S. E., and Vieira, S.: The role of deep roots in the hydrological and carbon cycles of Amazonian forests and pastures, Nature, 372, 666-669, doi:10.1038/372666a0, 1994.

Nepstad, D. C., Moutinho, P., Dias, M. B., Davidson, E., Cardinot, G., Markewitz, D., Figueiredo, R., Vianna, N., Chambers, J., Ray, D., Guerreiros, J. B., Lefebvre, P., Sternberg, L., Moreira, M., Barros, L., Ishida, F. Y., Tohlver, I., Belk, E., Kalif, K., and Schwalbe, K.: The effects of partial throughfall exclusion on canopy processes, aboveground production, and biogeochemistry of an Amazon forest, J. Geophys. Res.-Atmos., 107, 8085, doi:10.1029/2001JD000360, 2002.

Nepstad, D., McGrath, D., Stickler, C., Alencar, A., Azevedo, A., Swette, B., Bezerra, T., DiGiano, M., Shimada, J., da Motta, R. S., Armijo, E., Castello, L., Brando, P., Hansen, M. C., McGrath-Horn, M., Carvalho, O., and Hess, L.: Slowing Amazon deforestation through public policy and interventions in beef and soy supply chains, Science, 344, 1118-1123, doi:10.1126/science.1248525, 2014

Oki, T. and Kanae, S.: Global hydrological cycles and world water resources, Science, 313, 1068-1072, doi:10.1126/science.1128845, 2006.

Oliveira, L. J. C., Costa, M. H., Soares-Filho, B. S., and Coe, M. T.: Large-scale expansion of agriculture in Amazonia may be a nowin scenario, Environ. Res. Lett., 8, 024021, doi:10.1088/17489326/8/2/024021, 2013.

Oliveira, P. T. S., Nearing, M. A., Moran, M. S., Goodrich, D. C., Wendland, E., and Gupta, H. V.: Trends in water balance components across the Brazilian Cerrado, Water Resour. Res., 50, 7100-7114, doi:10.1002/2013WR015202, 2014.

Panday, P. K., Coe, M. T., Macedo, M. N., Lefebvre, P., and de Almeida Castanho, A. D.: Deforestation offsets water balance changes due to climate variability in the Xingu River in eastern Amazonia, J. Hydrol., 523, 822-829, doi:10.1016/j.jhydrol.2015.02.018, 2015.

Pokhrel, Y. N., Fan, Y., and Miguez-Macho, G.: Potential hydrologic changes in the Amazon by the end of the 21 st century and the groundwater buffer, Environ. Res. Lett., 9, 084004, doi:10.1088/1748-9326/9/8/084004, 2014.

Pongratz, J., Bounoua, L., DeFries, R. S., Morton, D. C., Anderson, L. O., Mauser, W., and Klink, C. A.: The impact of land cover change on surface energy and water balance in Mato Grosso, Brazil, Earth Interact., 10, 19, doi:10.1175/EI176.1, 2006.

Restrepo-Coupe, N., da Rocha, H. R., Hutyra, L. R., da Araujo, A. C., Borma, L. S., Christoffersen, B., Cabral, O. M. R., de Camargo, P. B., Cardoso, F. L., Lola da Costa, A. C., Fitzjarrald, D. R., Goulden, M. L., Kruijt, B., Maia, J. M. F., Malhi, Y. S., Manzi, A. O., Miller, S. D., Nobre, A. D., von Randow, C., Abreu Sa, L. D., Sakai, R. K., Tota, J., Wofsy, S. C., Zanchi, F. B., and Saleska, S. R.: What drives the seasonality of photosynthesis across the Amazon basin? A cross-site analysis of eddy flux tower measurements from the Brasil flux network, Agr. Forest
Meteorol., 182, 128-144, doi:10.1016/j.agrformet.2013.04.031, 2013.

Richards, P. D., Myers, R. J., Swinton, S. M., and Walker, R. T.: Exchange rates, soybean supply response, and deforestation in South America, Global Environmental Change-Human and Policy Dimensions, 22, 454-462, doi:10.1016/j.gloenvcha.2012.01.004, 2012.

Riskin, S.H., Porder, S., Neill, C., Michela e Silva Figueira, A., Tubbesing C., and Mahowald, N.: The fate of phosphorous fertilizer in Amazon soya bean fields, Philos. T. Roy. Soc. B, 368, 20120154, doi: 10.1098/rstb.2012.0154, 2013.

Rockström, J.: Water for food and nature in drought-prone tropics: vapour shift in rain-fed agriculture, Philos. T. Roy. Soc. London B, 358, 1997-2009, doi:10.1098/rstb.2003.1400, 2003.

Rockström, J. and Gordon, L.: Assessment of green water flows to sustain major biomes of the world: Implications for future ecohydrological landscape management, Physics and Chemistry of the Earth Part B-Hydrology Oceans and Atmosphere, 26, 843-851, doi:10.1016/S1464-1909(01)00096-X, 2001.

Rockström, J., Lannerstad, M., and Falkenmark, M.: Assessing the water challenge of a new green revolution in developing countries, P. Natl. Acad. Sci. USA, 104, 6253-6260, doi:10.1073/pnas.0605739104, 2007.

Rockström, J., Falkenmark, M., Karlberg, L., Hoff, H., Rost, S., and Gerten, D.: Future water availability for global food production: The potential of green water for increasing resilience to global change, Water Resour. Res., 45, W00A12, doi:10.1029/2007WR006767, 2009.

Rockström, J., Karlberg, L., Wani, S. P., Barron, J., Hatibu, N., Oweis, T., Bruggeman, A., Farahani, J., and Qiang, Z.: Managing water in rainfed agriculture-The need for a paradigm shift, Agr. Water Manage., 97, 543-550, doi:10.1016/j.agwat.2009.09.009, 2010.

Rockström, J., Falkenmark, M., Allan, T., Folke, C., Gordon, L., Jagerskog, A., Kummu, M., Lannerstad, M., Meybeck, M., Molden, D., Postel, S., Savenije, H. H. G., Svedin, U., Turton, A., and Varis, O.: The unfolding water drama in the Anthropocene: towards a resilience-based perspective on water for global sustainability, Ecohydrology, 7, 1249-1261, doi:10.1002/eco.1562, 2014.

Rodrigues, L. N., Sano, E. E., Steenhuis, T. S., and Passo, D. P.: Estimation of Small Reservoir Storage Capacities with Remote Sensing in the Brazilian Savannah Region, Water Resour. Manage., 26, 873-882, doi:10.1007/s11269-011-9941-8, 2012.

Rodrigues, T. R., Vourlitis, G. L., Lobo, F. D. A., de Oliveira, R. G., and Nogueira, J. D. S.: Seasonal variation in energy balance and canopy conductance for a tropical savanna ecosystem of south central Mato Grosso, Brazil, J. Geophys. Res.-Biogeosci., 119, 1-13, doi:10.1002/2013JG002472, 2014.

Rost, S., Gerten, D., Bondeau, A., Lucht, W., Rohwer, J., and Schaphoff, S.: Agricultural green and blue water consumption and its influence on the global water system, Water Resour. Res., 44, W09405, doi:10.1029/2007WR006331, 2008.

Rudel, T. K., Defries, R., Asner, G. P., and Laurance, W. F.: Changing drivers of deforestation and new opportunities for conservation, Conserv. Biol., 23, 1396-1405, doi:10.1111/j.15231739.2009.01332.x, 2009. 
Savenije, H. H. G.: Does moisture feedback affect rainfall significantly?, Phys. Chem. Earth, 20, 507-513, doi:10.1016/S00791946(96)00014-6, 1995.

Savenije, H. H. G.: The runoff coefficient as the key to moisture recycling, J. Hydrol., 176, 219-225, doi:10.1016/00221694(95)02776-9, 1996.

SEMA, Relatório de Monitoramento de Qualidade da Água - Região Hidrográfico Amazônica - 2012-2014, available at: http://www.sema.mt.gov.br/index.php?option=com_ docman\&Itemid=82, 2016.

Silvério, D. V., Brando, P. M., Macedo, M. N., Beck, P. S. A., Bustamante, M., and Coe, M. T.: Agricultural expansion dominates climate changes in Southeastern Amazonia: the overlooked non GHG-forcing, Environ. Res. Lett., 10, 104015, doi:10.1088/1748-9326/10/10/104015, 2015.

Simon, M. F. and Garagorry, F. L.: The expansion of agriculture in the Brazilian Amazon, Environ. Conserv., 32, 203-212, doi:10.1017/S0376892905002201, 2005.

Soares-Filho, B., Rajao, R., Macedo, M., Carneiro, A., Costa, W., Coe, M., Rodrigues, H., and Alencar, A.: LAND USE Cracking Brazil's Forest Code, Science, 344, 363-364, doi:10.1126/science.1246663, 2014.

Spera, S. A., Cohn, A. S., VanWey, L. K., Mustard, J. F., Rudorff, B. F., Risso, J., and Adami, M.: Recent cropping frequency, expansion, and abandonment in Mato Grosso, Brazil had selective land characteristics, Environ. Res. Lett., 9, 064010, doi:10.1088/1748-9326/9/6/064010, 2014.

Spracklen, D. V. and Garcia-Carreras, L.: The impact of Amazonian deforestation on Amazon basin rainfall, Geophys. Res. Lett., 42, doi:10.1002/2015GL066063, 2015.

Spracklen, D. V., Arnold, S. R., and Taylor, C. M.: Observations of increased tropical rainfall preceded by air passage over forests, Nature, 489, 282-U127, 2012.

Stickler, C. M., Coe, M. T., Costa, M. H., Nepstad, D. C., McGrath, D. G., Dias, L. C. P., Rodrigues, H. O., and Soares-Filho, B. S.: Dependence of hydropower energy generation on forests in the Amazon Basin at local and regional scales, P. Natl. Acad. Sci. USA, 110, 9601-9606, doi:10.1073/pnas.1215331110, 2013.
Strassburg, B. B. N., Latawiec, A. E., Barioni, L. G., Nobre, C. A., da Silva, V. P., Valentin, J. F., Vianna, M., and Assad, E. D.: When enough should be enough: Improving the use of current agricultural lands could meet production demands and spare natural habitats in Brazil, Global Environmental Change-Human and Policy Dimensions, 28, 84-97, doi:10.1016/j.gloenvcha.2014.06.001, 2014.

van der Ent, R. J. and Savenije, H. H. G.: Length and time scales of atmospheric moisture recycling, Atmos. Chem. Phys., 11, 18531863, doi:10.5194/acp-11-1853-2011, 2011.

van der Ent, R. J., Savenije, H. H. G., Schaefli, B., and Steele-Dunne, S. C.: Origin and fate of atmospheric moisture over continents, Water Resour. Res., 46, W09525, doi:10.1029/2010WR009127, 2010.

Velasquez, H. Q. C. and Bernasconi, P.: Fique por dentro: a Bacia do Rio Xingu em Mato Grosso, Instituto Socioambiental, Instituto Centro de Vida, São Paulo, Brazil, available at: http://www.icv.org.br/site/wp-content/uploads/2013/08/ 68180mioloatlasbaixa.pdf, 2010.

Vourlitis, G. L., Nogueira, J. d. S., Lobo, F. d. A., and Pinto Jr., O. B.: Variations in evapotranspiration and climate for an Amazonian semi-deciduous forest over seasonal, annual, and El Nio cycles, Int. J. Biometeorol., 59, 217-230, doi:10.1007/s00484014-0837-1, 2015.

Zeng, Z., Piao, S., Lin, X., Yin, G., Peng, S., Ciais, P., and Myneni, R. B.: Global evapotranspiration over the past three decades: estimation based on the water balance equation combined with empirical models, Environ. Res. Lett., 7, 014026, doi:10.1088/17489326/7/1/014026, 2012. 